\title{
DRESS Syndrome After Lamotrigine Use in An Epilepsy Patient: A Case Report
}

\section{Epilepsi Hastasında Lamotrijin Kullanımından Sonra DRESS Sendromu: Bir Olgu Sunumu}

\author{
Muhammet Mesut Nezir Engin ${ }^{1}$, Özlem Kaya ${ }^{1}$, Hacer Efnan Melek Arsoy ${ }^{1}$, \\ Serdar Pop ${ }^{1}$, Öner Özdemir ${ }^{2}$ \\ ${ }^{1}$ Sakarya Üniversitesi Eğitim ve Araştırma Hastanesi, Çocuk Sağlığı ve Hastalıkları Kliniği Sakarya \\ ${ }^{2}$ Sakarya Üniversitesi Eğitim ve Araştırma Hastanesi, Çocuk İmmünoloji ve Alerji Bilim Dalı Sakarya
}

\author{
Yazışma Adresi / Correspondence: \\ Muhammet Mesut Nezir Engin \\ Sakarya Üniversitesi Eğitim ve Araştırma Hastanesi Çocuk Sağlığı ve Hastalıkları Kliniği Adapazarı/Sakarya \\ T: +902644445400Ｅ-mail: doktormesut@hotmail.com \\ Geliş Tarihi / Received : 29.01.2021 Kabul Tarihi / Accepted : 26.05.2021 \\ Orcid: \\ Muhammet Mesut Nezir Engin https://orcid.org/0000-0002-0874-6857 \\ Özlem Kaya https://orcid.org/0000-0002-0901-981X \\ Hacer Efnan Melek Arsoy https://orcid.org/0000-0002-9812-5447 \\ Serdar Pop https://orcid.org/0000-0002-9833-728X \\ Öner Özdemir https://orcid.org/0000-0002-5338-9561 \\ ( Sakarya Tip Dergisi / Sakarya Med J 2021, 11(3):680-686) DOI: 10.31832/smj.706814 \\ Bu çalışma 17. Uludă̆ Kış Pediatri Kongresinde bildiri olarak sunulmuştur.
}

$\ddot{O} z$

DRESS (Drug Rash with Eosinophilia and Systemic Symptoms) sendromu ilaca bağlı akut bir așrı duyarlılık reaksiyonudur. DRESS sendromu; ates, deri döküntüsü, lenfadenopati, hematolojik anormallikler (eozinofili, atipik lenfositler), iç organ (karaciğer veya diğer) tutulumu ile karakterize olarak morbidite ve mortaliteye neden olabilir. DRESS sendromuna en sık neden olan ilaçlar antikonvülzanlar, dapson, sülfonamidler, allopurinol ve minosiklindir. Klinik bulgular genellikle sorumlu ilacın bașlamasından 1-7 hafta sonra gelișir, bu süre üç aya kadar uzayabilir. Ölüm oranının \% 10'lara kadar ulaștığını ve en önemli ölüm nedeninin karaciğer yetmezliği olduğunu bildiren makaleler vardır. DRESS sendromu için tanı kriterleri RegiSCAR grubu tarafından olușturulmuștur. Bu yazıda lamotrijin tedavisi sonrası DRESS sendromu gelișen bir çocuk olgusu sunularak güncel tanı ve tedavi yaklaşımları ile ilgili literatür gözden geçirilmiştir.

Anahtar antikonvülsan ilaç; DRESS sendromu; lamotrijin

kelimeler

Abstract

DRESS (Drug Rash with Eosinophilia and Systemic Symptoms) syndrome is an acute drug-induced hypersensitivity reaction. DRESS syndrome can cause morbidity and mortality, characterized by fever, skin rash, lymphadenopathy, hematological abnormalities (eosinophilia, atypical lymphocytes), internal (liver or other) organ involvement. Drugs that most commonly cause DRESS syndrome are anticonvulsants, dapsone, sulfonamides, allopurinol and minocycline. Clinical findings usually develop 1-7 weeks after the initiation of the responsible drug, this period may extend up to three months. There are reports stating that the mortality rate reaches up to 10\%, and the most important cause of mortality is liver failure. Diagnostic criteria for DRESS syndrome have been established by the RegiSCAR group. In this article, a pediatric case who developed DRESS syndrome after lamotrigine treatment was presented, and the literature on current diagnosis and treatment approaches was reviewed.

Keywords anticonvulsant drug; DRESS syndrome; lamotrigine 


\section{INTRODUCTION}

DRESS (Drug Rash with Eosinophilia and Systemic Symptoms) syndrome is an acute drug-induced hypersensitivity reaction. DRESS syndrome can cause morbidity and mortality, characterized by fever, skin rash, lymphadenopathy, hematological abnormalities (eosinophilia, atypical lymphocytes), internal (liver or other) organ involvement. The clinical situation observed with the use of the anticonvulsant drug hydantoin and its derivatives was named as "hydantoin hypersensitivity" in the 1940s. In 1988, it was named as "anticonvulsant hypersensitivity syndrome" to describe the symptoms associated with various aromatic anticonvulsant drugs (phenytoin, phenobarbital, primidone, carbamazepine, etc.). Bacquet et al. first named DRESS syndrome as acronym in $1996 .^{1-3}$

Drugs that most commonly cause DRESS syndrome are anticonvulsants, dapsone, sulfonamides, allopurinol and minocycline. DRESS syndrome due to aromatic anticonvulsant drugs usually occurs during the first exposure to the drug. The risk of developing DRESS syndrome during the first or second drug prescribing period is estimated at 1-4.5 cases/10000. Clinical findings usually develop 1-7 weeks after the initiation of the responsible drug, this period may extend up to three months. There are publications stating that the mortality rate reaches up to $10 \%$, and the most important cause of mortality is liver failure. Diagnostic criteria for DRESS syndrome have been established by the RegiSCAR group (Table 1$){ }^{4}$

In this article, a pediatric case who developed DRESS syndrome after lamotrigine treatment was presented, and the literature on current diagnosis and treatment approaches was reviewed.

\section{CASE REPORT}

A 13-year-old male patient was admitted to the pediatric emergency department with fever, anorexia and widespread skin rash. In his physical examination, his general condition was moderate, his body temperature was $39^{\circ} \mathrm{C}$, lymphadenopathy in the submandibular region and widespread maculopapular erythematous rashes were present on the whole body except his face (Figure 1). Other system examinations were normal. In the medical history of the patient, it was learned that he had been followed up for epilepsy for three years, used valproic acid treatment, and lamotrigine treatment was added after a convulsion two weeks ago. In laboratory examinations; hemoglobin 12.6 $\mathrm{g} / \mathrm{dl}$, leukocyte $6000 / \mathrm{mm}^{3}$, platelet $88000 / \mathrm{mm}^{3}$, in differential counts: neutrophil 58\%, lymphocytes $19.5 \%(8 \%$ atypical lymphocytes), eosinophils7\%, monocytes $12.4 \%$, and total eosinophil count was $424 / \mathrm{mm}^{3}$. In biochemical tests; AST 147 IU/L, ALT $113 \mathrm{IU} / \mathrm{L}$, total bilirubin 0.54 $\mathrm{mg} / \mathrm{dl}$, INR 1.3, APTT 29.9, prothrombin time $13.2 \mathrm{sec}$ ond and CRP $13 \mathrm{mg} / \mathrm{L}$ were detected. Complete urinalysis was normal. Urea, blood urea nitrogen and electrolytes were within normal limits. Antinuclear antibody, blood culture and serology for $\mathrm{HAV} / \mathrm{HBV} / \mathrm{HCV}$ were negative. Abdominal ultrasonography showed normal findings. The total score of the patient, (fever: 0, enlarged lymph nodes: 1 , skin rash suggesting DRESS: 1 , skin rash is present in> $50 \%$ of body surface area: 1 , liver involvement: 1 , hematological involvement: 1 and complete recovery after $>15$ days: 1) who was evaluated according to the RegiSCAR scoring system, was determined as 6, and a diagnosis of "definite" DRESS syndrome was made (Table 1$)^{5}$. The patient was admitted to the pediatric service for further follow-up and treatment with a pre-diagnosis of DRESS syndrome. Lamotrigine treatment was discontinued, supportive treatment and methylprednisolone $(2 \mathrm{mg} / \mathrm{kg} /$ day) treatment was initiated. Antihistamine treatment was not given, as it could trigger the convulsion. On the 3rd day of the follow-up, the patient whose general condition improved, fever regressed, oral intake was good, rashes started to decrease, thrombocytopenia regressed and other findings regressed was decided to be discharged. In the outpatient clinic follow-up, it was observed that his rashes completely disappeared on the 17 th day, and clinical and laboratory findings returned to normal. Signed informed consent was obtained from the family so that the medical 
Sakarya Med J. 2021;11(3):680-686

ENGIN et al.,A Case with DRESS Syndrome

\begin{tabular}{|c|c|c|c|c|c|}
\hline Score & -1 & 0 & 1 & 2 & Our case \\
\hline Fever $\geq 38,5^{\circ} \mathrm{C}$ & $\mathrm{No} / \mathrm{U}$ & Yes & & & 0 \\
\hline Enlarged lymph nodes & & $\mathrm{No} / \mathrm{U}$ & Yes & & 1 \\
\hline Eosinophilia & & $\mathrm{No} / \mathrm{U}$ & & & 0 \\
\hline Eosinophils & & & $0.7-1.49 \times 109 \mathrm{~L}-1$ & $\geq 1.5 \times 109 \mathrm{~L}-1$ & \\
\hline Eosinophils, if leucocytes $<4 \times 109 \mathrm{~L}-1$ & & & $\% 10-\% 19.9$ & $\geq \% 20$ & \\
\hline Atypical lymphocytes & & $\mathrm{No} / \mathrm{U}$ & Yes & & 0 \\
\hline \multicolumn{6}{|l|}{ Skin involvement } \\
\hline Skin rash extent (\% body surface area) & & $\mathrm{No} / \mathrm{U}$ & $>50 \%$ & & 1 \\
\hline Skin rash suggesting DRESS & No & $\mathrm{U}$ & Yes & & 1 \\
\hline Biopsy suggesting DRESS & No & $\mathrm{Yes} / \mathrm{U}$ & & & \\
\hline \multicolumn{6}{|l|}{ Organ involvement ${ }^{*}$} \\
\hline Liver & & $\mathrm{No} / \mathrm{U}$ & Yes & & 1 \\
\hline Kidney & & $\mathrm{No} / \mathrm{U}$ & Yes & & 0 \\
\hline Lung & & $\mathrm{No} / \mathrm{U}$ & Yes & & 0 \\
\hline Muscle/heart & & $\mathrm{No} / \mathrm{U}$ & Yes & & 0 \\
\hline Pancreas & & $\mathrm{No} / \mathrm{U}$ & Yes & & 0 \\
\hline Other organ & & $\mathrm{No} / \mathrm{U}$ & Yes & & 1 \\
\hline Resolution $\geq 15$ days & $\mathrm{No} / \mathrm{U}$ & Yes & & & 0 \\
\hline \multicolumn{6}{|l|}{ Evaluation of other potential causes } \\
\hline \multicolumn{6}{|l|}{ Antinuclear antibody } \\
\hline \multicolumn{6}{|l|}{ Blood culture } \\
\hline \multicolumn{6}{|l|}{ Serology for $\mathrm{HAV} / \mathrm{HBV} / \mathrm{HCV}$} \\
\hline \multicolumn{6}{|l|}{ Chlamydia/mycoplasma } \\
\hline If none positive and $\geq 3$ of above negative & & & Yes & & 1 \\
\hline \multicolumn{5}{|l|}{ Total score } & 6 \\
\hline
\end{tabular}

Table 2. Inclusion criteria for potential case of DRESS syndrome in RegiSCAR (2)

Hospitalization

Reaction suspected to be drug related

Acute skin rash

Fever above $38^{\circ} \mathrm{C}$

Enlarged lymph nodes at at least two sites

Involvement of at least one internal organ

Blood count abnormalities

Lymphocytes above or below the laboratory limits

Eosinophils above the laboratory limits (in percentage or

absolute count)

Platelets below the laboratory limits

The presence of 3 or more findings other than the first two findings is required. 
information and photographs of the patient could be used.

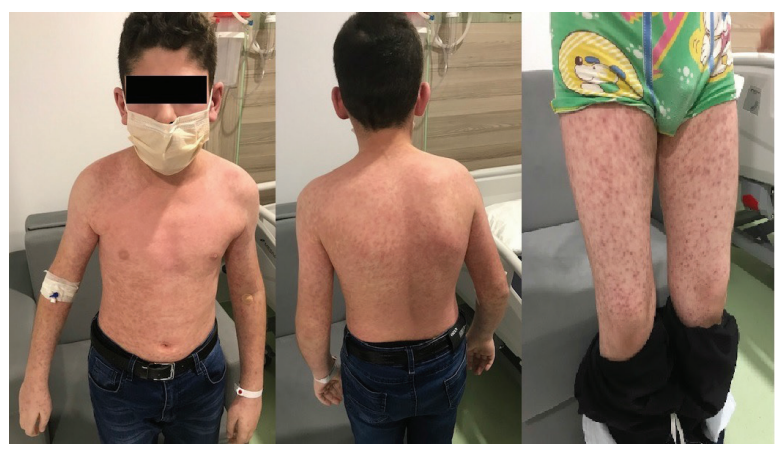

Figure 1. Widespread maculopapular rash observed in the patient.

\section{DISCUSSION}

A child patient admitted to the pediatric emergency service with fever and rash should be evaluated in terms of infection, allergic and rheumatological diseases. Pathogens of infectious disease, drug use history, history of exposure that may cause allergies and vaccine history should be questioned. Among infectious causes, rubeola, rubella, parvovirus B19, Epstein-Barr virus, cytomegalovirus, human herpes virus-6 and -7 (HHV-6 and -7) infections should be considered in the differential diagnosis. Systemic lupus erythematosus, juvenile dermatomyositis, juvenile idiopathic arthritis, Kawasaki disease and Henoch Schonlein purpura among rheumatologic diseases should be considered in the differential diagnosis. Sepsis and neoplastic diseases (lymphoma, leukemia, hypereosinophilic syndrome) are also included in the differential diagnosis of DRESS syndrome. Allergic reactions are divided into two main types: immediate and delayed onset. DRESS syndrome is considered as a type 4 hypersensitivity reaction among non-immediate drug reactions, and type 2 helper $\mathrm{T}$ cells play a role in the pathogenesis. ${ }^{5}$

DRESS syndrome is a rare and life-threatening delayed type drug hypersensitivity reaction in childhood. Although DRESS syndrome is defined as a delayed type drug hypersensitivity reaction, its etio-pathogenesis is not fully known yet. Lymphocyte activation, eosinophilia, viral fac- tors [especially HHV-6, HHV-7, EBV, HIV reactivations], and enzyme defects related to drug metabolism are among the factors held responsible in the etio-pathogenesis. Aromatic anticonvulsants (phenytoin, phenobarbital, carbamazepine, primidone, lamotrigine) metabolized by cytochrome p450 are converted into non-toxic metabolites by epoxide hydroxylase enzyme. A defect in this enzyme combined with other factors is thought to cause the DRESS syndrome. Therefore, it is safer not to choose aromatic anticonvulsants in patients with DRESS syndrome who may need antiepileptic treatment later. ${ }^{6}$ In our case, lamotrigine treatment, which is an aromatic anticonvulsant, was started two weeks before the symptoms.

The drugs most commonly reported to cause DRESS syndrome are aromatic anticonvulsants (phenobarbital, phenytoin, primidone, carbamazepine, lamotrigine), less frequently other anticonvulsants (valproic acid, ethosuximide), dapsone, sulfonamides and allopurinol. In addition, other drugs reported to cause DRESS syndrome very rarely; some antibiotics and antiviral drugs (minocycline, abacavir, neviparin, piperacillin, cidofovir, tazobactam, etc.), some anti-inflammatory drugs (naproxen, piroxicam, diclofenac, etc.), gold salts and angiotensin-converting enzyme inhibitors (enalapril, captopril). Especially vancomycin is one of the drugs recently blamed in DRESS etiology. ${ }^{6}$ Our case had a history of using valproic acid for three years and lamotrigine for the last two weeks. Lamotrigine was started in our case and we considered it as the causative agent of DRESS syndrome because it is in the aromatic group. Various skin rashes were reported in $16.5 \%$ of children using lamotrigine. Valproic acid inhibits the metabolism of lamotrigine, thus increasing the risk of lamotrigine-related reactions when used together. ${ }^{7}$ In our case, lamotrigine treatment was added when convulsions were observed while using valproic acid treatment, and our patient developed DRESS syndrome. Therefore, in epilepsy patients receiving valproic acid treatment, when convulsions cannot be controlled, a drug other than lamotrigine should be preferred as the second antiepileptic. 
It has been reported that epicutaneous patch testing with anticonvulsant drugs is useful and safe for detecting anticonvulsant drugs that induce DRESS syndrome and to determine safe alternative drugs. ${ }^{8}$

When we look at the clinical findings in DRESS syndrome, fever, rash, lymphadenopathy, hematological abnormalities (lymphocytosis, eosinophilia), hepatosplenomegaly and hepatitis can be seen. Pulmonary (interstitial pneumonia), renal, cardiac (myocarditis) and neurological (encephalitis) system involvements can also be seen in DRESS syndrome. It should be kept in mind that systemic involvements may occur weeks after the onset of the disease. The most important cause of mortality in DRESS syndrome is liver failure. Skin lesions range from diffuse maculopapular rash to erythroderma, rarely Stevens-Johnson syndrome and toxic epidermal necrosis are seen. In the study of the RegiSCAR group, 117 patients with DRESS syndrome were defined between 2003 and 2009, and it was reported that the skin rash in these cases was generally monomorphic maculopapular and less commonly as morbiliform erythema and erythrodermia. ${ }^{9}$ Our case had liver involvement (AST/ALT elevation), hematological (thrombocytopenia) involvement and maculopapular rash.

Among the laboratory findings that can be detected in DRESS syndrome, various hematological abnormalities (eosinophilia, leukocytosis, atypical lymphocytes, anemia, thrombocytosis, thrombocytopenia, etc.) are detected in 50-95\%. Eosinophilia, atypical lymphocytes, and leukocytosis can be seen at rates reaching 95\%, 67\% and 95\%, respectively. ${ }^{9}$ Our patient had borderline eosinophilia and thrombocytopenia.

The RegiSCAR study group is a working group that conducts prospective research to establish the follow-up and diagnostic criteria for Severe Cutaneous Adverse Reactions (SCAR) with a large and multinational registry system in Austria, France, Germany, Israel, Italy and the Netherlands. Inclusion criteria were established by the
RegiSCAR group to identify possible DRESS syndrome cases in order to provide a consensus in diagnosis (Table 2). A scoring system was created by the RegiSCAR group for the confirmation of DRESS syndrome. In the DRESS syndrome scoring system; $<2$ is evaluated as "no case", 2-3 "possible case", 4-5 "probable case" and $>5$ "definite case" (Table 1). ${ }^{2}$ In our patient, it was evaluated as 6 and "definite case" according to the scoring system.

Suspected drug should be stopped first in the treatment of DRESS syndrome. In the consensus report published by the French Dermatology Association; topical corticosteroids, moisturizers and $\mathrm{H} 1$-antihistamines in the absence of severe symptoms, prednisolone $1 \mathrm{mg} / \mathrm{kg} /$ day in the presence of severe symptoms (five-fold increase in transaminases, hemophagocytosis, pneumonia, cardiac involvement, visceral involvement) and multidisciplinary evaluation; in the presence of life-threatening findings (bone marrow failure, hemophagocytosis, renal failure, respiratory failure, encephalitis, severe hepatitis), 0.5-2 g/ $\mathrm{kg} /$ dose IVIG; in the presence of severe symptoms with major viral reactivation, steroid, antiviral agents and/or IVIG combination is recommended. In severe cases, it has been reported that generally good results are obtained by administering IVIG treatment at doses of $0.5-2 \mathrm{~g} / \mathrm{kg} / \mathrm{day}$ for one to four days. There is also some evidence that the addition of intravenous $\mathrm{N}$-Acetyl cysteine to the treatment prevents the progression of liver damage. ${ }^{9,10}$ In our case, lamotrigine was discontinued and methylprednisolone ( $1 \mathrm{mg} / \mathrm{kg} /$ day) and supportive therapy were given due to severe hepatitis and/or thrombocytopenia. Antihistamine treatment was not given because it might trigger the convulsion. IVIG treatment was planned if the patient's clinical condition deteriorated, but the patient recovered with the treatments given.

In conclusion, although viral infections are considered primarily in cases of suddenly rising fever, rash, hematological abnormalities and liver involvement, the drugs used recently should be questioned in terms of DRESS syndrome. 
When DRESS syndrome is considered, the suspected drug should be discontinued immediately. Although DRESS syndrome is similar to infectious diseases with a benign course, it is vital to consider in the differential diagnosis as it may have a mortal course. Therefore, we think that our article will contribute to the awareness of physicians about DRESS syndrome. 
Sakarya Med J. 2021;11(3):680-686

ENGIN et al.,A Case with DRESS Syndrome

\section{References}

1. Flippis R, Soldevila-Matías P, Fazio PD, Guinart D, Fuentes-Durá I, Rubio JM, et al. Clozapine-related drug reaction with eosinophilia and systemic symptoms (DRESS) syndrome: a systematic review. Expert Rev Clin Pharmacol 2020;13(8):875-883.

2. Kardaun SH, Sidoroff A, Valeyrie-Allanore L, Halevy S, Davidovici BB, Mockenhaupt M, et al. Variability in the clinical pattern of cutaneous side-effects of drugs with systemic symptoms: Does a DRESS syndrome really exist? Br J Dermatol 2007;156:609-11.

3. Ozdemir O. Development of antiepileptic hypersensitivity syndrome after phenytoin treatment. Turk J Pediatr. 2010; 52(1):111-2.

4. Kano Y, Ishida T, Hirahara K, et al. Visceral Involvements and Long-term Sequelae in Drug-induced Hypersensitivity Syndrome. Med Clin N Am 2010; 4: 743-59.

5. Criado PR, Criado RFJ, Avancini JM, Santi CG. Drug Reaction with Eosinophilia and Systemic Symptoms (DRESS)/DrugInduced Hypersensitivity Syndrome (DIHS): a review of current concepts. An Bras Dermatol 2012; 87: 435-449

6. O'Meara P, Borici-Mazi R, Morton AR, Ellis AK: DRESS with delayed onset acute interstitial nephritis and profound refractory eosinophilia secondary to vancomycin. Allergy Asthma Clin Immunol 2011;7:16.
7. Shiohara T, Inaoka M, Kano Y. Drug-induced hypersensitivity syndrome (DIHS): a reaction induced by a complex interplay among herpesviruses and antiviral and antidrug immune responses. Allergol Int. 2006; 55(1): 1-8.

8. Peyrière $H$, Dereure $O$, Breton $H$, et al. Variability in the clinical pattern of cutaneous side-effects of drugs with systemic symptoms: does a DRESS syndrome really exist? $\mathrm{Br} J \mathrm{Der}$ matol. 2006; 155(2): 422-8.

9. Kardaun SH, Sekula P, Valeyrie-Allanore L, Liss Y, Chu CY, Creamer D, et al. RegiSCAR study group. Drug reaction with eosinophilia and systemic symptoms (DRESS): An original multisystem adverse drug reaction. Results from the prospective RegiSCAR study. Br J Dermatol 2013;169:1071-80.

10. Moling O, Tappeiner L, Piccin A, Pagani E, Rossi P, Rimenti G, et al. Treatment of DIHS/ DRESS syndrome with combined $N$-acetylcysteine, prednisone and valganciclovir-a hypothesis. Med Sci Monit 2012;18:57-62. 